\title{
THE DEVELOPMENT HISTORY OF WIGRY LAKE AS SHOWN BY SUBFOSSIL CLADOCERA
}

\author{
EDYTA ZAWISZA and KRYSTYNA SZEROCZYŃSKA \\ Department of Quaternary Geology, Institute of Geological Sciences, \\ Polish Academy of Sciences, \\ Twarda 51/55, 00-818 Warsaw, Poland
}

Received 13 December 2006

Accepted 12 February 2007

\begin{abstract}
Environmental changes in Wigry Lake during the Late Glacial and Holocene were studied on the basis of subfossil Cladocera analysis. Cladocera are present in a long core WZS/03 (Słupiańska Bay), and a surface sediments. The sediment contains remains of twenty-seven species belonging to 5 families. Species composition of plankton and the variability in the frequency of specimens of Cladocera made possible to distinguish five phases of their development, which well correlated with palynological phases. The correlation proves that the biological development of Wigry Lake was determined mainly by climatic changes. During the history of the lake, planktonic forms were dominant and represented by Bosminidae. It indicates that the lake was (excluding the initial part) deep and oligo- or mesotrophic. The mesotrophic state has been noted during the Atlantic chronozone and temporary. Taking into consideration the size and the depth as well as the rare human population around the lake it can be stated that the trophy rise was the result of the warm climate. It is also possible that during the last few decades the natural and anthropogenic factors could add. Probably mild winters, warm and long summers, increased tourists number were partly responsible for changes of water state.
\end{abstract}

Keywords: Wigry Lake, subfossil Cladocera, climate, trophy state

\section{INTRODUCTION}

Paleolimnological research is being extensively developed in various research institutes around the world. This research is very important in the reconstruction of paleoenvironment and paleoclimate. Lake and peat bog sediments consist the natural archives, thus they are extensively studied. In these sediments remains of fauna are well preserved, e.g. the remains of Cladocera. Microscopic analysis of their remains allows to determine their species or even subspecies (Frey, 1986; Korhola and Rautio, 2001; Szeroczyńska, 1985, 1998a). Knowing the climatic and ecological requirements of contemporary species, the fossil material can be successfully used to reconstruct these conditions in the past (Korhola, 1999; Lotter and Boucherle, 1984; Sarmaja-Korjonen, 2002; Szeroczyńska, 2002). Lake sediments are the archives facilitating the reconstruction of changes of the climate

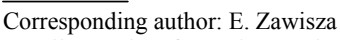

e-mail: ezawisza@twarda.pan.pl and ecology of a site (Mirosław-Grabowska and Niska, 2005; Milecka and Szeroczyńska, 2005; SarmajaKorjonen and Alhonen, 1999). Sediments make it possible to reconstruct changes of trophy, of the water salt content and pH (Amsinck et al., 2003; Korhola and Tikkanen, 1991; Nilssen and Sandøy, 1986). Results of analysis of Cladocera subfossils are also helpful in the reconstruction of the lake development, changes occurring during sedimentation. Moreover, they are often used in environment protection studies. They can be used to determine human impact on the lake condition (Szeroczyńska, 1998b; Szeroczyńska, 2002). Bottom deposits analysis provides important information concerning temperature and hydrology changes and also trophy level (Alhonen, 1970; Hofmann, 1996; Lotter et al., 2000). Extremely important is the possibility of analysis of trophy changes in Holocene, in particular natural and human factors (Bałaga et al., 2002; Gąsiorowski and Szeroczyńska, 2004; Milecka and Szeroczyńska, 2005). In order to predict the water quality in lake, its contemporary and historic conditions must be known. In Poland, expect 
mountain lakes, studies of subfossil of Cladocera were done for not-deep lakes with high deposit thickness of sediments, their development was strictly dependent on human activity (Bałaga et al., 2002; Gąsiorowski and Nalepka, 2003; Szeroczyńska, 1985; 2003; Szeroczyńska and Gąsiorowski, 2004).

In this work we present results of analysis of sediments from Wigry Lake. Wigry Lake is deep and contains sediments of low deposit thickness (Rudowski et al., 2001; Rutkowski et al., 2002, 2003, 2007; Piotrowska et al., 2007). Our research shows significant differentiation of sediments and difference in sedimentation velocity, indicating very differentiated reach ecosystem. Wigry Lake is located in NE Poland in the most cold and notdensity populated region of the country, giving a unique opportunity to analyze changes in the environment influenced mainly by climate on the background of other sites (Kupryjanowicz, 2007).

\section{MATERIALS AND METHODS}

In summer 2003, in the central part of the Słupiańska Bay,a sediment core from the profile WZS/03 (27$526 \mathrm{~cm}$ ) was taken using a Więckowski corer (Rutkowski et al., 2007). Surface sediments $(0-44 \mathrm{~cm})$ were collected from the same area, using a Kajak gravity corer in summer 2004. The sediments were analyzed, at intervals of $1 \mathrm{~cm}$ in the case of surface sediments, and $10 \mathrm{~cm}$ in the case of the WZS/03 profile. The cladoceran remains were prepared according to Frey (1986). Each sample $\left(1 \mathrm{~cm}^{3}\right.$ of fresh sediments) was boiled for half an hour in a $10 \%$ solution of $\mathrm{KOH}$ to remove humic matter and treated with $\mathrm{HCl}$ to eliminate carbonates. The residue was washed and sieved using a $40 \mu \mathrm{m}$ sieve. The final residue was filled up to $10 \mathrm{ml}$ with distilled water. The $0.1 \mathrm{ml}$ solution was used for every microscope slide. All remains were counted: headshields, shells, postabdomens, postabdominal claws and ephippia. 2-6 slides were counted from each sample, depending on the abundance of remains. In further analysis the population was taken into account. The Cladocera remains were screened using an OLYMPUS microscope. Cladocera taxonomy followed by Flössner (1972 and 2000), Frey (1991), Goulden and Frey (1963) and Szeroczyńska and Zawisza (2005).

\section{RESULTS}

In the analyzed profile $\mathrm{WZS} / 03$ and the profile of $40 \mathrm{~cm}$ of surface sediments, 27 species of Cladocera were found (Fig. 1). The found Cladocera belongs to 5 families, namely Bosminidae, Daphnidae, Leptodoridae, Sididae and Chydoridae. Cladocera belonging to the Bosminidae, Daphnidae, Leptodoridae families consist of open water zooplankton, whereas Chydoridae to littoral zone. The results, obtained from the analysis of sediments taken from long and short cores are shown on diagrams (Fig. 2a, b; 3a, b). This analysis provided temperature and trophy changes in the lake during the deposition of sediments. During the overall time of the lake existence, the main plankton consisted of species of Bosminidae. In the Late Glacial communities of littoral family were dominant. In this period, Chydoridae had an abundance

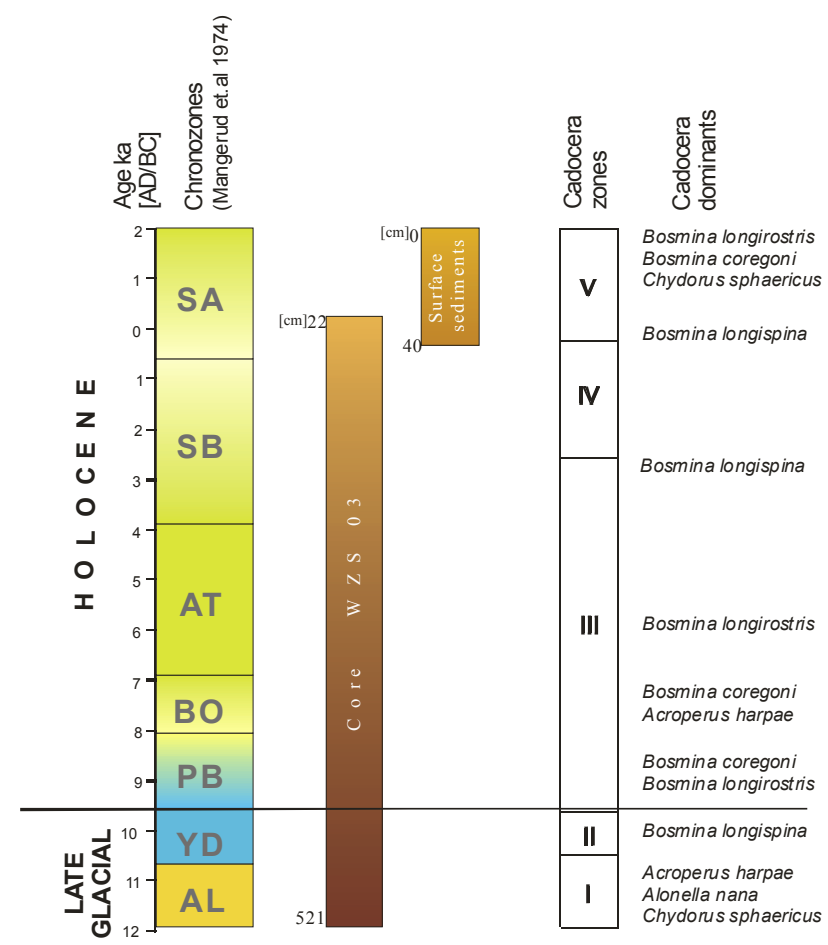

Fig. 1. The dominating species of Cladocera in Wigry Lake (core WZS/03 and surface sediments) compared with chronozones and

of up to $90 \%$. Changes of the particular species existence and the frequency of specimens allowed to distinguish 5 phases of Cladocera development. These phases overlap with the biological development of Wigry Lake.

\section{Profile: WZS/03}

Phase I - 13733 - 12415 cal BP $(526-470 \mathrm{~cm})$

Low number of individuals of Cladocera species characterized the initial period of the lake development. Changes of species belonging to Chydoridae and appearance of Bosminidae family were the background to two separate subphases:

subphase $a$ - only six species were found, which were dominated by pioneer species Acroperus harpae, Alona affinis and Chydorus sphaericus, so called "arctic species". In the bottom part of the profile sand sediments were found, in these sediments Cladocera remains were absent,

subphase $b$ - is characterized by increase of Cladocera, the number of species increased to ten. Species belonging to the littoral zone were dominant. However, Bosmina longispina living in open-water zone was noted. It is worth to emphasize here that stenothermal species Camptocercus rectirostris was present.

Phase II - 12415 - 11563 cal BP $(470-455 \mathrm{~cm})$

This period is characterized by significant decrease of number of species (to 5) and specimens. In sediments remains of following species, belonging to cold-water were found: Bosmina longispina, Acroperus harpae, Alonella nana, Chydorus sphaericus and Eurycercus lamellatus. Species living in warmer water, which were found in Ib, did not appear at all. 
Phase III - 11563 - $4502 \mathrm{cal} \mathrm{BP}(455-242 \mathrm{~cm})$

It is a long period whose boundaries were determined basing on the presence of two species: Bosmina longirostris $i$ Bosmina coregoni. This phase is characterized by the highest development of Cladocera fauna. Species belonging to the open water zone (Bosminidae) were dominant. Moreover, in this period also the highest number of the littoral species was found. Their population was for about $47 \%$. In this period the maximal development of stenothermal and planktonic species was found (Fig. 2a, b; 3a, b).

Based on change in domination of Bosminidae taxa, this phase was divided into four subphases a, b, c, d as follows

subphase $a$ - species Bosmina coregoni and Bosmina reflexa were dominant,

subphase $b$ - the population of Bosminidae decreased and in parallel the population of Chydoridae increased to $47 \%$ (Fig. 2a, 3a),

subphase $c$ - domination of Bosmina longirostris. This subphase was the best for development of Cladocera species during the history of the lake,

subphase $d$ - in this time Bosmina longispina dominated. The littoral species decreased to $17 \%$ (Fig. 3a).

Phase IV - 4502 - 2299 cal BP $(242-142 \mathrm{~cm})$

During this phase Bosmina longispina dominated as well. The specimens belonging to Bosmina coregoni were very rare, whereas remains belonging to Bosmina longirostris were not found. Changes in the ratio of planktonic to littoral species allowed to isolate 2 subphases:

subphase $a$ - characterized by large content of Chydoridae, in particular Acroperus harpae, Chydorus sphaericus and Euryercus lamellatus,

subphase $b$-dominated by the presence of planktonic Bosmina longispina, and among littoral species Chydoridae the genus Alona.

Phase V- 2299 - 240 cal BP $(142-27 \mathrm{~cm})$

Phase V - again was characterized by the development of the species requiring higher temperature and trophy. Changes of various species of Bosminidae allowed dividing this period in two subphases:

subphase a - gradual increase of Bosmina longispina specimens was observed and the number of species of the littoral zone increased but stenothermal species were not found,

subphase $b$ - characterized by the appearance of species of open-water: Bosmina coregoni and Bosmina reflexa. The frequency of littoral species increased up to $40 \%$ including stenothermal taxa, namely Camptocercus rectirostris and Pleuroxus trigonellus (Fig. 2a, 3a).

\section{Surface sediment WZS/03a}

2003 - $1560 \mathrm{cal}$ AD $(0-42 \mathrm{~cm})$

In the study, the sediments of the top-most layer $(42 \mathrm{~cm})$ deposited contemporarily are very important. ${ }^{210} \mathrm{~Pb}$ isotopic analysis (Gąsiorowski and Hercman, unpublished) indicates that the described here sediments $(0-30 \mathrm{~cm})$ were deposited during the last 300 years. The top layers (including 1-2 cm) were deposited in ca. 2000 year.
Analysis of subfossil Cladocera in the surface sediment layer was done with $1 \mathrm{~cm}$ resolution. Such detailed research allowed the interpretation of conditions during sedimentation. Species diversity and frequency of various species suggest that the sediments layer $42-30 \mathrm{~cm}$ deep was deposited in the same time as sediment in the core WZS/03: 30-27 cm deep (subphase Vb). Species composition and frequency of Cladocera in the surface sediments (profile $0-42 \mathrm{~cm}$ - core obtained by gravity corer) allowed to distinguish the following subphase in phase $\mathrm{V}$ :

subphase $b$ - except Bosmina reflexa, the diversity of species was the same as in phase $\mathrm{Vb} \mathrm{WZS} / 03$,

subphase $c$ - subfossil remains of Bosmina longirostris were found. These remains have not appeared in sediments since early Subboreal chronozone. In this phase, a maximal development of Camptocercus rectrirostris (Fig. 2b) was found. The littoral species reached $46 \%$ (Fig. 3b),

subphase $d$-domination of planktonic species belonging to Bosminidae, in particular Bosmina longispina. The littoral species decreased,

subphase $e$ - taxa of Daphnia longispina group and Leptodora kindti appeared. In general, the fauna was dominated by species characteristic to open-water. Chydoridae family was the most frequent, including Chydorus sphaericus.

\section{Correlation with literature data}

For the first time, analysis of the subfossil Cladocera in sediments from Wigry Lake was carried out already in the 70's (Czeczuga and Kossacka, 1977). Czeczuga and Kossacka performed the analysis of the content of Cladocera remains, which allowed to present ecological changes taking place in various parts of the Wigry Lake during Holocene period. The comparison of the results from the 70's and ours is difficult due to tremendous changes in the methodology of Cladocera. The comparison of qualitative analysis points at good correlation. Czeczuga and Kosacka reported 32 various species belonging to 3 families, whereas we report 27 species belonging to 5 families. Czeczuga and Kosacka (1977) did not find remains of the planktonic taxa: Daphnia longispina - group and Leptodora kindti, but they reported richer composition of littoral species (Chydoridae). These differences originate from various localization of cores and differences in thickness of collected sediments. The sediments (thickness of $14 \mathrm{~m}$ ) analyzed by Czeczuga and Kosacka were cored from the littoral zone, while we performed subfossil Cladocera analysis in sediment of WZS/03 which was taken from the open-water zone (18.2 m. water).

Comparison of quantitative analysis in these two cases is difficult. The subfossil Cladocera diagrams showing percent content (Czeczuga and Kosacka, 1977) do not provide clear picture of climate changes. In periods of colder climate, it can happen (in particular in deep lakes) that the frequency of specimens decreases but the number of species remains unchanged. In this case, only diagrams of absolute concentration can indicate the decrease of Cladocera and worse conditions for their existence, reflecting temperature changes. Taking this into 


\begin{tabular}{|c|c|c|c|c|c|c|}
\hline & б & $\begin{array}{ll}\text { D } & \text { व }\end{array}$ & 각 & 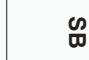 & & $\stackrel{S}{D}$ \\
\hline$\sum_{\leq}$ & $\sum_{i} \sum_{i}$ & $\sum$ & 衿 & $\sum_{S}$ & $\sum_{i=1}$ & $\sum_{\infty} \sum_{\phi}$ \\
\hline $\bar{\alpha} \bar{\sigma}$ & $=\overline{\overline{\mathrm{\nu}}}$ & $\overline{\bar{\nu}} \overline{\bar{\nu}}$ & $\overline{\bar{\partial}}$ & $\overline{\bar{\alpha}} \underset{ঐ}{\nwarrow}$ & $\bar{\delta}$ & $\varsigma \delta$ \\
\hline
\end{tabular}

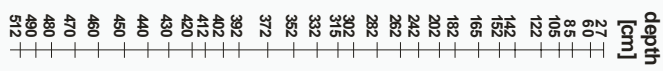

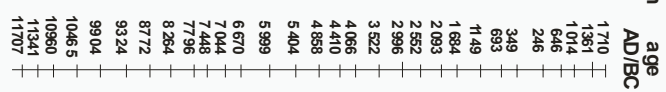

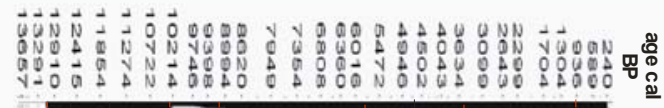

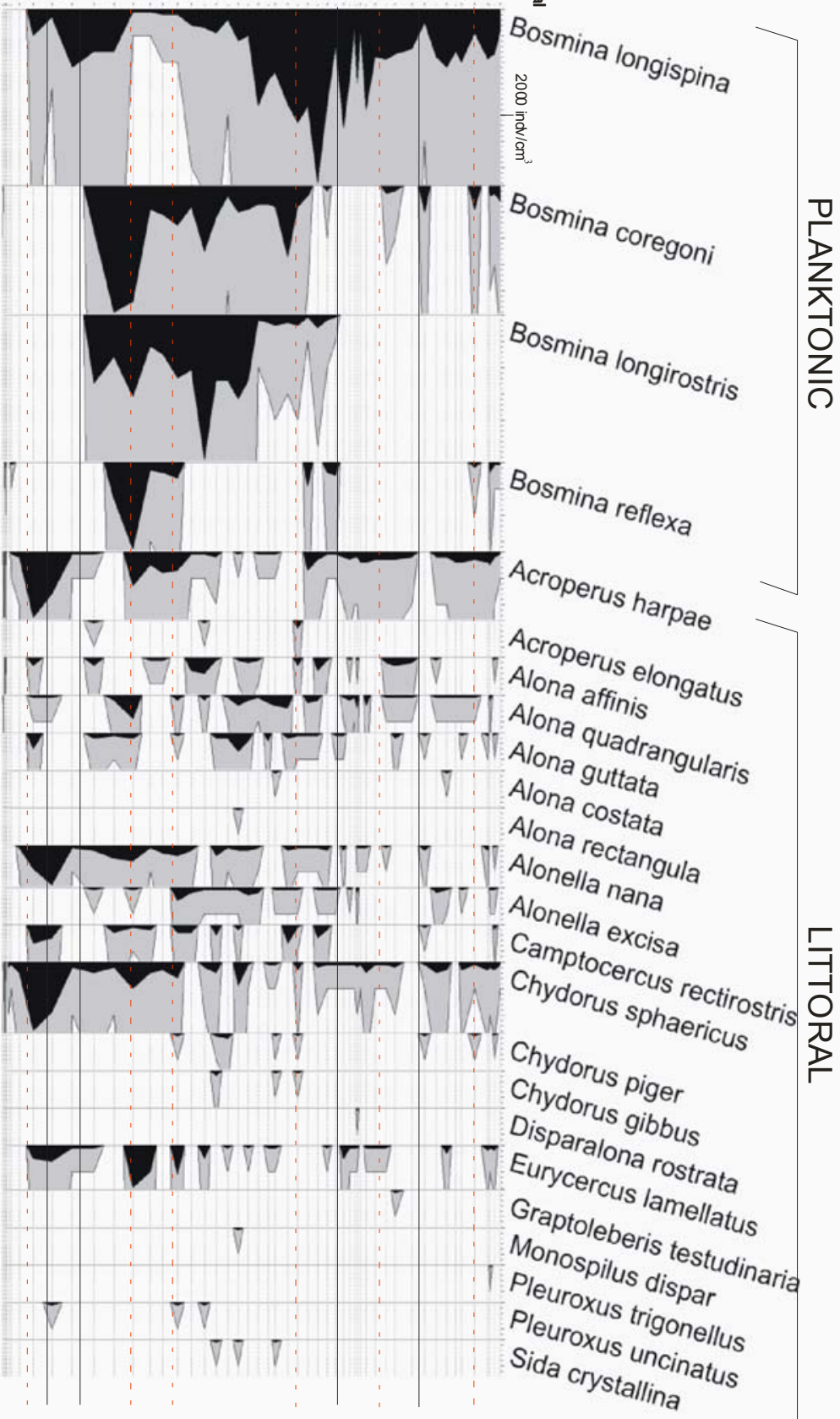




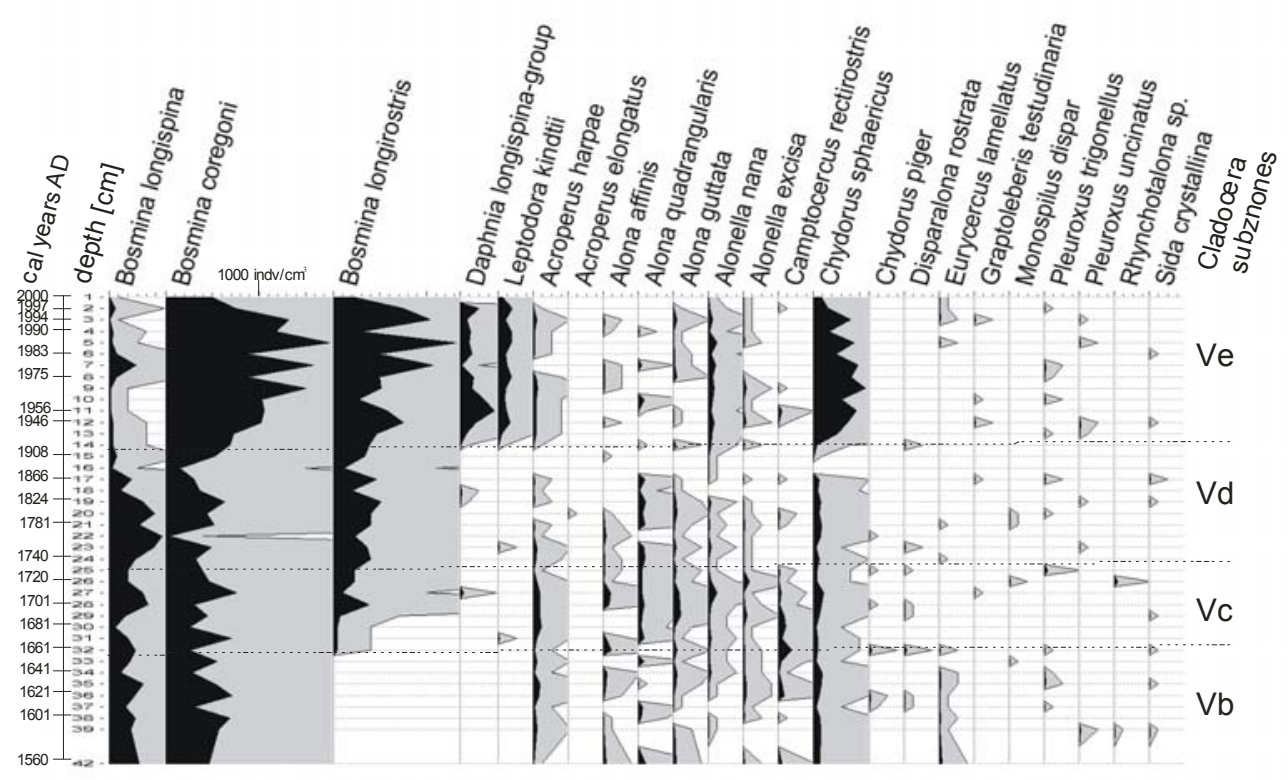

Fig. 2b. Diagram of the absolute number of Cladocera individuals in the surface sediments of Wigry Lake.

account we do not compare the quantitative analysis of Cladocera species from these two papers.

\section{INTERPRETATION AND DISCUSSION}

Species composition of Cladocera in sediments from Wigry Lake, and characteristic of its changes allowed to analyze the history of the development of the lake from Allerød until present, and made it possible to distinguish 5 phases of its evolution.

Phase I represents in R PAZ W-1, and corresponds to Allerød. Analysis of species composition of Cladocera show that in the first part (subphase Ia) of Allerød the climate was colder, and the temperature of water did not favor the zooplankton development. In this time, only pioneer species, tolerant to cold water and low level of biogenic substance existed. They are so called "arctic species" (Whiteside, 1970). In the analyzed layer of sediment containing more sand, we did not find Cladocera remains. An increase of sand concentration in sediments may be due to the delivery of mineral material from the lake's banks or melting blocks of death ice. In the initial period, Wigry Lake contained less water and its trophy was probably formed at the level of oligotrophy. Similar picture of domination of pioneer species in initial period was reported in many lakes of Central and North Europe (Gąsiorowski and Szeroczyńska, 2004; Sarmaja-Korjonen and Alhonen, 1999; Szeroczyńska, 1985). In younger Allerød (subphase Ib), an increase of zooplankton development was found. It is connected with the improvement of climatic conditions, which took place in the second half of this period. The number of species increased from 6 to 10 and the specimens of Cladocera from 400 to 50000. Species Camptocercus rectirostris and Pleuroxus uncinatus (Poulsen, 1928) requiring warmer water were found. The level of water in the lake probably increased which is mirrored by an increase of Cladocera species. Parallel to littoral species, Bosmina longispina - typical for open-water was found. The trophy of the lake did not change, remained on the level of oligotrophy.

Phase II corresponds to R PAZ W-2, W-3 and belongs to Younger Dryas. In this period only littoral "arctic species" were found and one open-water species Bosmina longispina.

Phase III existed during chronozones: from Preboreal to Subboreal (R PAZ W-3, W-4, W-5 and W-6). It is the period of optimal development among all Cladocera species, both living in open-water and littoral zone. The lake was dominated by deep-waters Bosminidae. In this period also the number of species and specimens of littoral zone was the highest. The high species diversity and concentrations indicate that there were optimal conditions for zooplankton, suggesting higher temperature and trophic state. The maximum of zooplankton development was in Atlantic (subphase IIIc). In this time the optimal development of Bosmina longirostris indicating increased trophy was found. Moreover, species Camptocercus rectirostris and Pleuroxus uncinatus belonging to littoral zone and preferring warmer waters were present. The trophy of the lake in this period had probably mezotrophic character. The species composition and population of Cladocera corresponds to the climatic optimum of the Holocene (Alhonen, 1970; Gąsiorowski and Szeroczyńska, 2004). In the Atlantic's optimum, based on subfossil Cladocera, water level oscillation, is not clear. The determination of the water level in Wigry Lake, analyzing Cladocera species is difficult due to maximal development of Bosmina longirostris. This species lives in deep and shallow lakes having increased trophy, and their domination, generally, indicates high state of trophy. However, it seems that Wigry Lake in climate optimum had a high water level as in previous phase. This can be confirmed by diatom analysis, lithology (Rutkowski et al., 2007).

On the border of Atlantic and Subboreal chronozones (subphase IIId) the analysis show domination of deepwaters Bosmina longispina and in parallel decrease of 


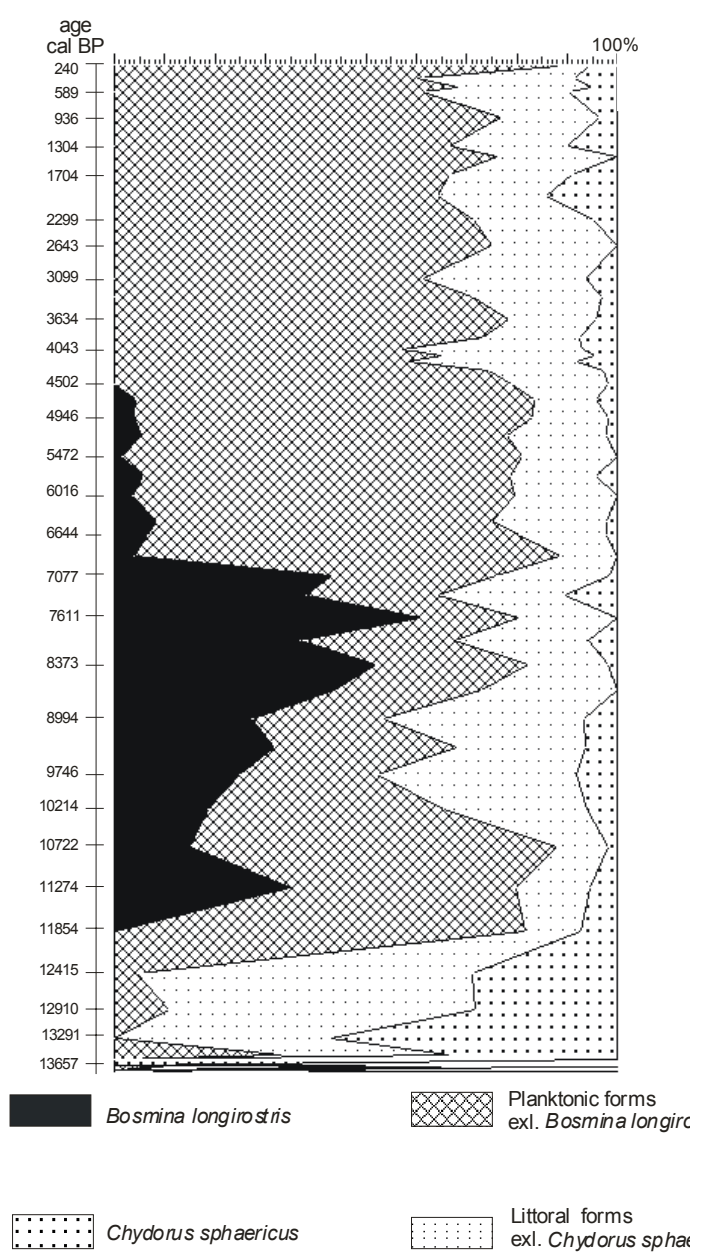

Fig. 3a. Ratio of planktonic to littoral species of Cladocera in the sediment of Wigry Lake (core WZS/03).

taxa Bosmina longirostris and B. coregoni, indicating increase of water level and decrease in trophy.

Phase IV corresponds to end part of R PAZ W-6 and $\mathrm{W}-7$ and is correlated with Subboreal chronozone. In this period conditions for development of Cladocera in Wigry Lake decreased. In this phase there were no stenothermal species present, probably indicating that water temperatures were lower than during the previous phase. The frequency and number of species belonging to littoral forms also significantly decreased, only remains of ten species were found. Their frequency was reduced to $22 \%$ (Fig 3b). The planktonic form Bosmina longispina was dominant indicating low trophy of water (Hofmann, 1977). Existence of this species indicates that the lake in this period was oligotrophic and deep one.

Phase $\mathbf{V}$ is recorded in R PAZ W-8 and W-9 layers and corresponds to Subatlantic chronozone. It is characterized by slow increase of the number and communities of the open-water and littoral species. At the beginning of this phase Bosmina longispina species dominated. In littoral zone, nine species were found and Acroperus harpae and Chydorus sphaericus dominated this ecosystem. The composition of species indicates that water in the lake was cold, in particular in first-half of Subatlantic

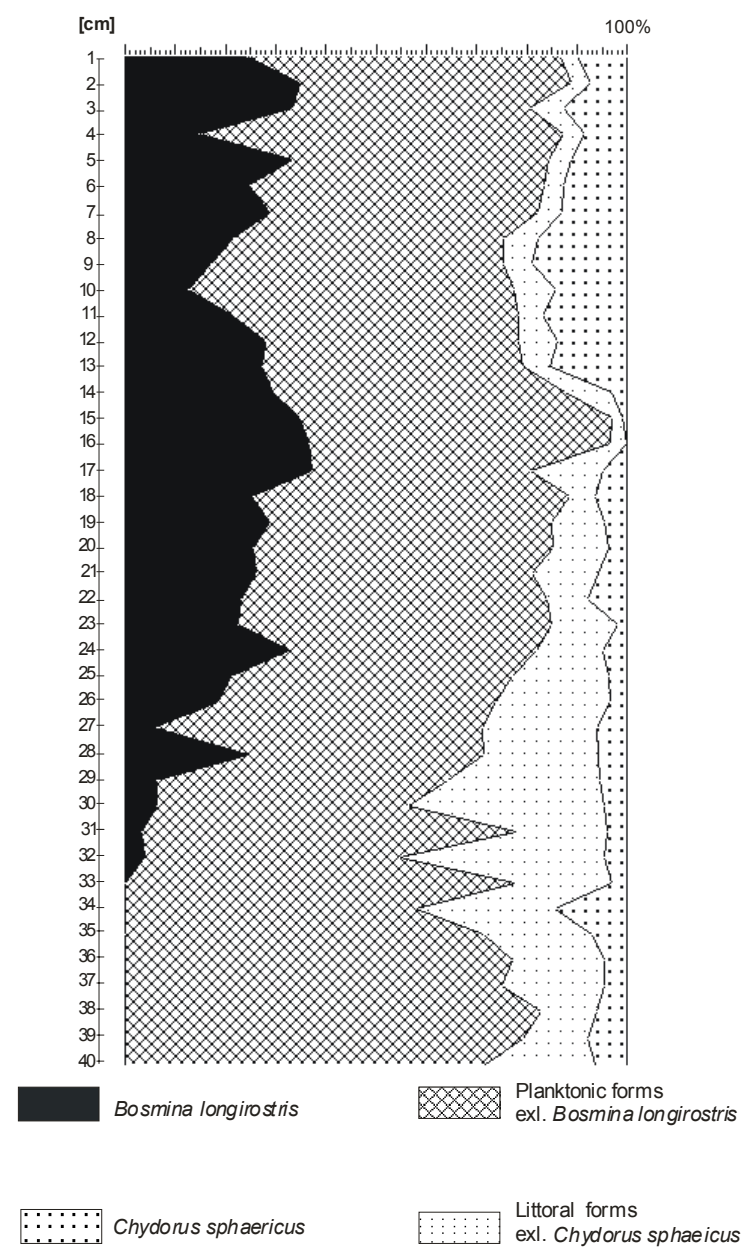

Fig. 3b. Ratio of planktonic to littoral species of Cladocera in the surface sediment of Wigry.

chronozone. In the second half of the period of Subatlantic an increase of Bosmina species was observed. Species requiring warm water and higher trophy existed in the lake. For the first time following taxa of open-water zone were found: Daphnia longispina-group and predator species Leptodora kindti. At the end of phase V, Bosmina longirostris in the lake gradually increased. Increased frequency of $B$. longirostris was parallel with increase of the $B$. coregoni, while the specimens of $B$. longispina systematically decreased. The Bosminidae changes point at an increase of water trophy (Goslar et al., 1999; Hofmann, 1996; Szeroczyńska, 1985). Presence of the remains of Daphnia longispina-group and Leptodora kindti in sediments suggest low fishes pressure (Jeppensen et al., 1996). In the youngest sediments a decrease of most of littoral species was observed, as well as development of Chydorus sphaericus, Alonella nana and Acroperus harpae species typical for cold waters. Maximal development of Bosmina longirostris and Chydorus sphaericus indicates an increase of the trophy during last tens of years (Hofmann 1996). This phenomenon is observed in many shallow lakes in North Poland, which is often due to human activity (Szeroczyńska, 1998b). However the Wigry Lake is large and deep, and in addition its vicinities are scarcely-populated, then the trophy seems rather 
connected with climate warming than human activity (Kupryjanowicz, 2007). Changes in carbon isotopes ratio (unpublished) reported for the upper part of the profile of sediments indicate a continuous increase of the state of the trophy in Wigry Lake (Słupiańska Bay), in particular during the last 3-10 $\mathrm{cm}$ deposit layer. This suggests that not only natural, but also anthropogenic factors influence the lake's condition. During the sedimentation of the youngest sediments $(0-3 \mathrm{~cm})$ a decrease of Cladocera population is observed. In this case it is hard to state if this decrease resulted from the decrease of biogenic substance or dilution of the sample.

The lake, during its development was deep with developed pelagic zone, what is confirmed by domination of planktonic forms belonging to the family of Bosminidae. Bosminidae lived in Wigry Lake in all phases of its development, except its initial period (phase I). The variety of species of Cladocera belonging to Chydoridae confirms a well developed and diversificated littoral zone. Changes in the species composition point at the existence of the lake in of oligotrophic (phases: I, II, IV) or mezotrophic (phases: III,V) forms. The reported phases of lake evolution and Cladocera development (I-V) correlated well with climatic periods determined on the basis of palynological analysis (Kupryjanowicz, 2007).

\section{FINAL REMARKS}

Over all period of the Lake Wigry existence the main component of zooplankton were pelagial species of Cladocera belonging to Bosminidae family. Changes of the species and of their specimens allowed to separate five phases of Cladocera development, thus the phases of the biological development of Wigry Lake. The results of qualitative and quantitative analysis of Cladocera allowed a detailed reconstruction, both in time and location, of changes taking place in the lake and its vicinity.

Five phases of Cladocera development (I-V) correlate well with palynologically found phases (R PAZ W-1 W-9) indicating that the biological development of the lake was dependent mainly on the climate changes $(\mathrm{Ku}-$ pryjanowicz, 2007). The lake (expect its early times) over all time was deep and its trophy was from oligo- to mesotrophy status. The mesotrophic state was found during climate optimum and at present. Taking into account the size and depth of the lake and rare population of it is surroundings, it is suggested that the increase of the lake trophy was mainly due to warm Atlantic climate (phase III) and contemporary warm-climate (phase V). Probably, during the last 30 years, changes in the trophy were influenced not only by natural but also by human factors, what was indicated by another analysis (palynologycal - Kupryjanowicz, 2007). Nowadays, relatively warm winters and longer and warmer summers and an increased tourist activity may influence the water condition in Wigry Lake.

\section{REFFERNCES}

Alhonen P, 1970. On the significance of the planktonic/littoral ratio in the cladoceran stratigraphy. Commentationes Biologicae 35: 1-9.
Amsinck SL, Jeppensen E and Ryves D, 2003. Cladoceran stratigraphy in two shallow brackish lakes with special reference to changes in salinity, macrophyte abundance and fish predation. Journal of $\mathrm{Pa}$ leolimnology 29: 495-507.

Bałaga K, Szeroczyńska K, Taras H and Magierski J, 2002. Natural and anthropogenic conditioning of the development of Lake Perespilno (Lublin Polesie) in Holocene. Limnological Review 2: 15-27.

Czeczuga B and Kossacka W, 1977. Ecological changes in Wigry Lake in the post-glacial period. Part II. Investigations of the Cladoceran Stratigraphy. Polskie Archiwum Hydrobiologii 24: 259-277.

Flössner D, 1972. Branchiopoda, Branchiura. Die Tierwelt Deutschlands 60: 1-501

Flössner D, 2000. Die Haplopoda und Cladocera (ohne Bosminidae) Mitteleuropas (Haplopoda and Cladocera (without Bosminidea) of Central Europe). Backhuys Publisher, Leiden, The Nethrlands: pp. 428.

Frey DG, 1986. Cladocera analysis. In: Berglund BE, ed., Handbook of Holocene palaeoecology and palaeohydrology. John Wiley \& Sons Ltd.: 667-692.

Frey DG, 1991. First subfossil records of Daphnia headshelds and shells (Anomopoda, Daphniidae) about 10000 years old from northernmost Greenland, plus Alona guttata (Chydoridae). Journal of Paleolimnology 6: 193-197.

Gąsiorowski M and Nalepka D, 2003. Rekonstrukcja środowiska przyrodniczego kopalnego jeziora w Osłonkach na Kujawach na podstawie wyników analizy wioślarek i analizy pyłkowej. (Reconstruction of paleoenvironment of fossil lake in Osłonki (Kujawy, Poland) based on cladoceran and pollen analyses). Prace $i$ materiaty Muzeum Archeologicznego i Etnograficznego $w$ Lodzi. Seria Archeologiczna 42: 35-52 (in Polish).

Gąsiorowski M and Szeroczyńska K, 2004. Abrupt changes in Bosmina (Cladocera, Crustacea) assemblages during the history of the Ostrowite Lake (northern Poland). Hydrobiologia 526: 137-144.

Goslar T, Ralska-Jasiewiczowa M, Bas van Geel, Łącka B, Szeroczyńska K, Chróst L and Walanus A, 1999. Anthropogenic changes in the sediment composition of Lake Gościąż (central Poland), during the last 330 yrs. Journal of Paleolimnology 22: 171-185.

Goulden, CE and Frey DG, 1963. The occurrance and significance of lateral head pores in the genus Bosmina (Cladocera). International Review ges. Hydrobiologie 48: 513-522.

Hofmann W, 1977. Bosmina (Eubosmina) populations of the Grosser Segeberger See during late-glacial and postglacial times. Archivum für Hydrobiologie 80: 349-359.

Hofmann W, 1996. Empirical relationships between cladoceran fauna and trophic state in thirteen northern German lakes: analysis of surficial sediments. Hydrobiologia 318, 195-201.

Jeppesen E, Madse EA, Jensen JP and Andersen NJ, 1996. Reconstructing the past density of planktivorous fish and trophic structure from sedimentary zooplankton fossils: A surface sediment calibration data set from shallow lakes. Freshwater Biology 36: 115-127.

Korhola. A, 1999. Distribution patterns of Cladocera in subarctic Fennoscandian lakes and their potential in environmental reconstruction. Ecography 22: 357-373.

Korhola A and Tikkanen M, 1991. Holocene development and early extreme acidification in small hilltop lake in southern Finland. Boreas 20: 333-356.

Korhola A and Rautio M, 2001. Cladocera and other branchiopod crustaceans. In: Smol J.P., Birks H.J.B., Last W.M. (eds), Tracking Environmental Change Using Lake Sediments, Zoological Indicators. Kluwer Academic Publishers, Dordrecht, 4: 5-41.

Kupryjanowicz M, 2007. Postglacial development of vegetation in the vicinity of the Wigry Lake. Geochronometria 27: 53-66, DOI 10.2478/v10003-007-0018-x.

Lotter A and Boucherle MM, 1984. A Late-Glacial and Post-Glacial history of Amsoldingersee and vicinity, Switzerland. Schweiz Zeittschrift für Hydrologie 46: 192-209.

Lotter AF, Birks HJB, Eicher U, Hofmann W, Schwander J and Wick L, 2000. Younger Dryas and Allerød summer temperatures at Gerzensee (Switzerland) inferred from fossil pollen and cladoceran assemblages, Palaeogeography Palaeoclimatology Palaeoecology 159: 349-361.

Milecka K and Szeroczyńska K, 2005. Changes in macrophytic flora and planktonic organisms in Lake Ostrowite, Poland, as a response to climatic and trophic fluctuations. The Holocene 15: 74-84.

Mirosław-Grabowska $\mathrm{J}$ and Niska M, 2005. Isotopic and Cladocera records of climate changes of Early Eemian at Besiekierz (Central Poland). Geological Quarterly 49: 67-74. 
Nilssen JP and Sandøy S, 1986. Acidification history and crustacean remains: some ecological obstacles. Hydrobiologia 143: 349-354.

Piotrowska N, Hajdas I, Bonani G, 2007. Construction of the calendar time scale for Lake Wigry (NE Poland) sediments on the basis of radiocarbon dating. Radiocarbon 49(2): in print.

Poulsen E M, 1928. Freshwater crustacea. In: Jensen A D, Lundbeck W, Mortensen Th, Sparck R and Tuxen S L (eds). 1928-1971. The Zoology of the Faroes I-III, I 31: 1-21.

Rudowski S, Rutkowski J, Król K and Krzysztofiak L, 2001. O niektórych strukturach sedymentacyjnych $\mathrm{w}$ osadach dennych jeziora Wigry w świetle badań sejsmoakustycznych (Some sedimentological structures in Lake Wigry sediments in the light of seismoacustic investigations.). Sprawozdania z czynności i posiedzeń PAU 64: 191-194 (in Polish).

Rutkowski J, Król K, Krzysztofiak L and Prosowicz D, 2002. Recent sediments of the Lake Wigry (Bryzgiel Basin). Limnological Review 2: 353-362.

Rutkowski J, Król K, Krzysztofiak L and Prosowicz D, 2003. Recent sediments of the Wigry Lake (Szyja Basin), NE Poland. Limnological Review 3: 197-204.

Rutkowski J, Król K, Szczepańska J, 2007. Lithology of the profundal sediments in Słupiańska Bay (Wigry Lake, NE Poland) - introduction to interdisciplinary study. Geochronometria 27: 47-52, DOI 10.2478/v10003-007-0020-3.

Sarmaja-Korjonen K and Alhonen P, 1999. Cladoceran and diatom evidence of lake-level fluctuations from a Finnish lake and the effect of aquatic-moss layers on microfossil assemblages. Journal of Paleolimnology 22: 277-290.
Sarmaja-Korjonen K, 2002. Multi-proxy data from Kakoislammi Lake in Finland: dramatic changes in the late Holocene cladoceran assemblages. Journal of Paleolimnology 28: 287-296.

Szeroczyńska K, 1985. Cladocera jako wskaźnik ekologiczny w późnoczwartorzędowych osadach jeziornych Polski Północnej (Cladocera as ecological indicator in late Quaternary lacustrine sediments in Northern Poland). Acta Palaeontologica Polonica 30: 3-69 (in Polish with English summary).

Szeroczyńska K, 1998a. Wioślarki (Cladocera, Crustacea) jako źródło informacji $\mathrm{W}$ badaniach osadów jeziornych. (Cladocera (Crustacea) as informations sourse in studies of lake sediments). Studia Geoogica Polonica 112: 9-28 (in Polish with English summary).

Szeroczyńska K, 1998b. Anthropogenic transformation of nine lakes in Central Poland from Mesolithic to modern times in the light of Cladocera analysis. Studia Geologica Polonica 112: 123-165.

Szeroczyńska K, 2002. Human impact on lakes recorded in the remains of Cladocera (Crustacea). Quaternary International 95-96: 165174.

Szeroczyńska K, 2003. Cladoceran succession in lakes and peat bogs of Łęcznma-Włodawa Lake District. Limnological Review 3: 235242.

Szeroczyńska K and Gąsiorowski M, 2004. From Cladocera remains to the reconstruction of human influence on lakes. Annual Report 2004, Polish Academy of Sciences: 86-88.

Szeroczńska K and Zawisza E, 2005. Daphnia remains from the sediments of lake Somaslampi (NW Finnish Lapland) and Lake Wigry (NE Poland). Studia Quaternaria 22: 55-57.

Whiteside MC, 1970. Danish Chydorid Cladocera: modern ecology and core studies. Ecology Monogrphy, 40: 79-118. 